\title{
Soil contamination and human health: part 3
}

\author{
Jaume Bech
}

Published online: 29 October 2020

(C) Springer Nature B.V. 2020

\section{Background}

This collection of papers submitted to this Special Issue is mainly an outcome of the Session SSS8.5, EGU2018 "Soil contamination and human health: advances and problems of risk assessment", the European Geosciences Union (EGU) Conference held in Vienna, April 2018.

Development of soil geochemistry and geochemical ecology has demonstrated a correlation between concentration of certain elements and organic compounds in soil, their transfer to local food chains and biological reactions to deficiency or excess that can originate serious health problems. It is necessary to establish the optimal level for population health and evaluate the spatial distribution of soil chemicals above or below these optimal levels.

This Special Issue contains 24 papers written by authors from 16 countries: Brazil China, India, Iran, Italy, Japan, Republic of Korea, Malaysia, Pakistan, Portugal, Russian Federation, South Africa, Spain, Thailand, Tunisia and Vietnam.

This collection of papers is mainly focused on seven topics:

J. Bech ( $\square)$

Emeritus Professor University of Barcelona (UB),

Barcelona, Spain

e-mail: jaumebechborras@gmail.com
1. Soils close to mining, metallurgical processes, oil production and other industrial areas.

2. Drinking water, groundwater, wastewater.

3. Organic pollutants.

4. Urban soils.

5. Agricultural soils.

6. Radionuclides.

7. Transfer trace elements in the ocean-atmospherecontinent system.

8. Trace metals in a permafrost affected soil.

In the following paragraph, I will summarize the content and main results of these papers published in this Special Issue.

\section{Research topics}

Soils close to mining, metallurgical processes, oil production and other industrial areas

There are twelve papers dealing with this first topic, soils close mining, metallurgical, oil production and other industrial areas:

Rossini-Oliva et al. (2020) investigated the potential risk of adverse effects for human health posed by plant food cultivation soils in the vicinity of two $\mathrm{Mn}$ and $\mathrm{Fe}$ abandoned mines of Ferragudo and Rosalgar (Portugal). The authors studied cabbage and oregano and estimated and characterized the soil-plant system and potential risk, based on the estimation of metal 
daily intake (EDI), assessed in a microcosm assay under greenhouse conditions. In both soils, the concentrations of $\mathrm{Fe}$ and $\mathrm{Mn}$ were above the normal values, as well in shoots of both species. Cabbage behaved as an excluder of $\mathrm{Cu}, \mathrm{Mn}, \mathrm{Fe}$ and $\mathrm{Zn}$. The EDI for $\mathrm{Cu}, \mathrm{Fe}, \mathrm{Mn}$ and $\mathrm{Zn}$ in the studied species grown on both soils was lower than the tolerable upper EDI. Therefore, its consumption is safe.

Linnik et al. (2020) deal with the geochemical assessment and spatial analysis of heavy metal (HM) pollution around Novocherkassk coal-fired power station, Rostov Region, Russia. The 25 soil samples selected in the area within a radius of up to $20 \mathrm{~km}$ revealed enrichment with $\mathrm{Pb}, \mathrm{Cu}$ and $\mathrm{Zn}$. The $\mathrm{HM}$ content in soil following a decreasing sequence: $\mathrm{Mn}>\mathrm{Cr}>\mathrm{Zn}>\mathrm{Ni}>\mathrm{Cu}>\mathrm{Pb}>\mathrm{Co}$. The correlation diagrams of the HM total content revealed a significant association in the pairs: $\mathrm{Cu}-\mathrm{Pb}, \mathrm{Ni}-\mathrm{Cu}$, $\mathrm{Cd}-\mathrm{Ni}, \mathrm{Cd}-\mathrm{Cu}(r \geq 0.7, p<0.001)$. The influence of wind rhumb $\mathrm{HM}$ on distribution is complex and nonlinear.

Mishra et al. (2020) researched the phytoremediation potential of naturally growing plant species in the zinc-contaminated electroplating site in Faridabad, Haryana state, India. Soil enzymatic activities were determined. Relative frequency (RF), relative density (RD), relative abundance (R.Ab.) and importance value index (IVI) of naturally growing plant community on $\mathrm{Zn}$-sludge-contaminated site were calculated. The IVI calculated revealed Chrozophora tinctorea and Desmotachya bipinnata which were the most important species followed by Commelia diffusa, Chloris virgata, Cynodon dactylon and Eleusina indica. C. tinctorea, C. virgata, C. diffussa, $C$. dactylon and D. bipinnata, with translocation factor $\mathrm{TF}>1$, that would be potential species for extracting $\mathrm{Zn}$. All these six plant species with bioconcentration factor BCF values $>1$ would be useful for stabilizing $\mathrm{Zn}$.

Kumar et al. (2020) investigated $\mathrm{Cu}, \mathrm{As}, \mathrm{Cd}, \mathrm{Hg}$, $\mathrm{Co}, \mathrm{Mn}, \mathrm{Pb}$ and $\mathrm{Zn}$ contamination in the soils around an old $\mathrm{Cu}$ smelter in Karabash, Russia, and potential human health risk assessment. The average concentrations of $\mathrm{Cu}, \mathrm{Zn}, \mathrm{Pb}$, $\mathrm{As}, \mathrm{Cd}$ and $\mathrm{Hg}$ in the polluted soil were much higher than reference soil values. Except $\mathrm{Co}$ and $\mathrm{Mn}$, the enrichment factor (EF) for $\mathrm{Cu}$, $\mathrm{Hg}, \mathrm{Pb}$ and $\mathrm{Zn}$ showed a significant increase and very high levels for As and $\mathrm{Cd}$. The pollution load index was tenfold higher than the acceptable level of one, which suggests that the main source of contamination is the old $\mathrm{Cu}$ smelter. The results of the potential risk factor suggest $\mathrm{As}>\mathrm{Pb}>\mathrm{Cu}>\mathrm{Hg}$ as major contributors to health risks for children and adults. Hence, preventive measures are required to protect the soil quality and public health.

Khelifi et al. (2020) evaluated the geochemical distribution and oral bioaccessibility of potentially toxic elements (PTE) $\mathrm{Cd}, \mathrm{Cr}, \mathrm{Cu}, \mathrm{Mn}, \mathrm{Pb}$ and $\mathrm{Zn}$ in soil, sediments and phosphate-mining wastes from Gafsa mining basin (SW Tunisia). Cd, $\mathrm{Cr}$ and $\mathrm{Zn}$ were found in high concentrations, exceeding in many cases the international standards for PTE. The sequential extraction (modified EU-BCR) of the PTE of these neighbouring mine soils revealed that the most-easilyextractable fractions of each PTE was very low $(<10 \%)$. Cd was associated with $\mathrm{OM}$, while $\mathrm{Cr}$ and $\mathrm{Mn}$ were found in the residual fraction. The total concentration of each metal was found higher in the close mine soils than in phosphate rock. The Unified BARGE (UBM) Method for oral bioaccessibility assessment showed a higher bioaccessibility of PTO in the gastric fluid than in the gastrointestinal phase.

Nguyen et al. (2020) examined the contamination by potentially harmful elements in paddy soil in the vicinity of the Nui Phao multi-metal mine in Thai Nguyen province, North Vietnam. The authors analysed the concentration of $\mathrm{As}, \mathrm{Cd}, \mathrm{Cr}, \mathrm{Cu}, \mathrm{Pb}$ and $\mathrm{Zn}$ in the collected soil samples. The results showed that all soil samples were contaminated by As $(50.93 \mathrm{mg} / \mathrm{Kg})$ and $\mathrm{Cd}(15.22 \mathrm{mg} / \mathrm{Kg})$ values that exceeded largely the Vietnamese soil quality standard for agriculture. The contamination factor, enrichment factor, the pollution index, the geo-accumulation index, the contamination degree and the ecological risk factor were used. The obtained values indicated high As and Cd pollution and slight-to-moderate $\mathrm{Pb}>\mathrm{Cr}>\mathrm{Cu}>$ $\mathrm{Zn}$ pollution. Therefore, the residents should be concerned about non-carcinogenic effects and cancer risk.

Pobi et al. (2020) investigated the degree of heavy metal pollution and their sources in the soils of Durgapur industrial area, India. The authors also evaluate the potential ecological and human health risk posed by the concentrations of $\mathrm{Pb}, \mathrm{Cd}, \mathrm{Cr}, \mathrm{Fe}, \mathrm{Cu}$, $\mathrm{Ni}$ and $\mathrm{Hg}$ in studied soils and also their spatial variability. The results of enrichment factor, contamination factor, pollution load index and geo-accumulation index show high contamination and high 
potential ecological risk by $\mathrm{Cd}$ and $\mathrm{Hg}$ for all soil samples, while the risk for other heavy metals are moderate. Human health hazard indices are lower than 1 for all metals, indicating low non-carcinogenic risks to children and adults.

Kapwata et al. (2020) analysed the spatial concentrations and pollution levels of $\mathrm{Pb}, \mathrm{As}, \mathrm{Hg}$ and $\mathrm{Cd}$ in residential soils in rural Giyani, Limpopo province, South Africa. The authors used portable XRF spectrometer, and levels were compared with South African soil screening levels and Canadian reference levels. The results showed elevated levels of As, which exceeded international recommendations. According the geo-accumulation index, the most polluted site was found Igeo class 2-5. Also, a north-south gradient for As contamination was identified in the northern of this site in a possible gold mining area.

Ko et al. (2020) investigated the contamination in soil and plant levels and sources of As and $\mathrm{Cd}$ in the vicinity of a tungsten mine in Nui Phao (Vietnam). Both soil and rice grain samples had been contaminated with As and $\mathrm{Cd}$ that exceeded the Vietnamese soil quality criteria and CODEX standards. The distribution of As concentration is related to the distance from the Nui Phao mine. However, the $\mathrm{Cd}$ distribution in soil showed a different pattern from As. Enrichment factor and geo-accumulation index indicated that the As in the soil is derived from the mining activities, while the $\mathrm{Cd}$ could have other geogenic or anthropogenic sources. The As concentration between soil and plant samples showed a positive correlation, while the Cd correlation is negative.

Han et al. (2020) assessed Cd and Zn immobilization in soil using five sequential extraction methods and lettuce cultivation experiments. Paddy soils contaminated with $\mathrm{Cd}$ and $\mathrm{Zn}$ were collected from around abandoned metal mines in Korea. Limestone and steel slag were mixed with the collected soil, as amendments for $\mathrm{Cd}$ and $\mathrm{Zn}$ immobilization. The exchangeable fraction of $\mathrm{Cd}$ and $\mathrm{Zn}$ was decreased using amendments. The accumulation of $\mathrm{Cd}$ and $\mathrm{Zn}$ in lettuce decreased in treated soil, indicating a $\mathrm{Cd}$ and $\mathrm{Zn}$ immobilization effect in soil by the amendments. The extraction results by $\mathrm{CaCl}_{2}$ and Mehlich methods present more reasonable results for $\mathrm{Cd}$ and $\mathrm{Zn}$ immobilization in soil than EDTA, DTPA and TCLP methods. Therefore, the choice of appropriate extraction method is decisive in the assessment of $\mathrm{Cd}$ and $\mathrm{Zn}$ immobilization efficiency.

Naz et al. (2020) studied the ecological and human health impact of heavy metals in six native plant species with ethnobotanical significance growing at the largest chromite mine in India. Exchangeable, oxidizable, reducible and residual fractions of metals in plant rhizosphere were analysed. Only $2-6 \%$ of total $\mathrm{Cr}$ and $\mathrm{Ni}$ at the mine site is bioavailable. Cd showed highest bioavailability, posing very high ecological risk, followed by $\mathrm{Ni}$ and $\mathrm{Cr}$. The total hazard quotient (THQ) through the consumption of plants growing in mining region was very high $(>1)$ in the order of Euphorbia hirta (5.9) $>$ Calotropis procera (4.8) $>$ Argemone mexicana $\quad(3,6)>$ Vernonia cinerea $(3.5)>$ Pteridium latiusculum (3.4) $>$ Tridax procumbens (2.6) through the consumption pathway growing in heavy-metal-polluted soil, which should be avoided as they are dangerous to health.

Jiang et al. (2020) assessing Litchi branch biochar (BC) application to immobilized $\mathrm{Cd}$ and $\mathrm{Pb}$ in a contaminated soil near Dabaoshan Mine, South China, through a field experiment under a cucumber-sweet potato-rape rotation. The results showed that the application of BC increases the $\mathrm{pH}, \mathrm{CEC}$ and $\mathrm{SOC}$ and reduces the available $\mathrm{Cd}$ and $\mathrm{Pb}\left(\mathrm{CaCl}_{2}\right.$-extractable $)$. The highest application dose of $\mathrm{BC}\left(30 \mathrm{tha}^{-1}\right)$ is the most efficient in reducing soil $\mathrm{CaCl}_{2}$-extractable $\mathrm{Cd}$ and $\mathrm{Pb}$ and increasing $\mathrm{pH}$ and dissolved organic carbon (DOC) concentration in the soil solution. The yield and chlorophyll contents of cucumber, sweet potato and rape all increase with the increase in $\mathrm{BC}$ application. Under one-year cucumber-sweet potatorape rotation, the positive effect of $\mathrm{BC}$ to immobilize heavy metals in soil is still maintained.

Drinking water, groundwater, wastewater

Three papers in this Special Issue are concerned with the third topic, drinking water, groundwater, waste water:

Kumar et al. (2020) investigated the groundwater agricultural soil quality and associated health risks in the agri-intensive region of the Sutlej River Basin of Punjab, India. The authors applied the Pearson correlation matrix and principal component analysis to explore the correlation and source apportionment analysis for the contaminants. The distribution of groundwater and agricultural soil contaminants is 
illustrated using the IDW interpolation technique. The results show that the level of $\mathrm{U}$ and $\mathrm{Se}$ in groundwater exceeded the WHO/BIS limit at nearly $25 \%$ of sites. The groundwater and soil of this region are suitable for agricultural purposes. The sources of $\mathrm{Cr}, \mathrm{Zn}$ and $\mathrm{Pb}$ in the soils of steel Mandi Gobindgarh, an eastern part of Fatehgarh Sahib, have industrial activities present in these areas. As and $\mathrm{Cr}$ are the potential carcinogens in some parts of this district.

Parvanak and Khamisabadi (2020) studied contamination impact of wastewater irrigation to soils in Zahedan refinery, Iran. The authors employed a fieldexperimental method in the statistical form of totally random blocks with three reiterations of treatments. For this, they used three pieces of land: one of grass irrigated with wastewater; a second irrigated with well water and a third that was the green spaces of Zahedan refinery. Soils and wastewater and wall water composition were analysed by standard methods and by statistic MSTAT-C software. Results show the modified degree of contamination $(\mathrm{mCd})<1$, which indicate low contamination status. The concentration of $\mathrm{S}, \mathrm{N}, \mathrm{Mg}, \mathrm{Zn}, \mathrm{Mn}, \mathrm{Cu}$ in the experimental lands was enriched. Igeo $\leq 1$ indicate no contamination. Therefore, in these arid and semiarid areas, the wastewater outlet of this treatment plant should be considered as an important source of water.

Sanwar et al. (2020) evaluated the potential impacts of the high levels of metal built up in soilplant system after irrigation with untreated city wastewater. This arises from the effluents of dozens of cotton seed oil manufacturing and cotton processing factories, directly discharged into nearby canals/ streams or into municipal disposal points in Vehary, Pakistan. The authors studied the content in $\mathrm{Cd}, \mathrm{Cr}$, $\mathrm{Cu}, \mathrm{Fe}, \mathrm{Ni}, \mathrm{Mn}, \mathrm{Pb}$ and $\mathrm{Zn}$ of wastewater, soil and plant, collected from 15 peri-urban sites. Results showed that the mean concentrations $(\mathrm{mg} / \mathrm{L})$ of $\mathrm{Cd}$ (0.02), $\mathrm{Mn}(0.25)$ and $\mathrm{Fe}$ (1.57) in wastewater samples exceeded their threshold values and the permissible limits of agricultural soil receiving wastewater irrigation. The plants also exceeded the limits of accumulation of $\mathrm{Pb}, \mathrm{Cr}$ and $\mathrm{Fe}$, but depending of each vegetable/crop species. The health risk parameters to human health showed that daily intake of $\mathrm{Pb}$ and $\mathrm{Cd}$ from crop plants irrigated with these wastewaters.
Organic pollutants

There are three papers in this Special Issue refer to the second topic, organic pollutants:

Egorova and Buzmakov (2020) assessed the level of PCBs contamination of soils and biota (Ficedula hypoleuca) and the carcinogenic and teratogenic status of human populations in the Industrialniy and Leninsky districts of Perm (Russia). The concentration of PCBs in soils of the Industrialniy district exceeded, by four times, than that in the soils of the Leninsky district of Perm. The concentration of PCBs in the blood of $F$. hypoleuca in the Industrialniy district was higher than in nestlings from the Leninsky district. The cancer rates in Perm were similar to those for the country as a whole and lower than for cities with a high level of PCB concentration. The frequency of congenital malformations (CMFs) in Perm exceeded that for Russia as a whole. It was not possible to establish a relationship between the concentration of PCBs in soli and biota and the frequency of cancer and CMFs in the city population. Nevertheless, the results suggest that the presence of PCBs in the environment was one important factor affecting the health of the population and birds of the Perm.

Tao et al. (2020) studied the pollution level, distribution and characteristics of phthalate acid esters (PAEs) in agricultural soils of Yinchuan, NW China. The authors collected 89 soil samples and detected for 16 PAEs. The mean and median concentrations of $\sum 16$ PAEs were 4.277 and $4.427 \mathrm{mg} \mathrm{Kg}^{-1}$, respectively, and DEP, DMP, DIBP and DEHP were detected. DMP, DBP and DEHP were the main pollutants in Yinchan soils. In addition, the potential health risk exposures to local resident of 6 priority control PAEs by the US EPA were assessed. The carcinogenic risk of DEHP exceeded the threshold level by the US EPA.

Zhang et al. (2020) determined concentration, distribution, sources and potential risk of polycyclic aromatic hydrocarbons (PAHs) in urban Greenland soils of Nanjing, China. The PAHs were determined on soil samples from six functional zones: residential zone (RZ), business zone (BZ), industrial zone (IZ), cultural and educational zone (CZ), urban park (UP) and urban rural forest (URF). Results showed that the average concentration of $\sum$ PAHs was $499.47 \mathrm{ng} / \mathrm{g}$, value comparable to similar cities. The highest value was in IZ. Acenaphthene was the dominant compound. 
$\sum$ PAH of IZ showed the highest values in all soil layers. Petroleum combustion was the main source of PAHs. The benzo(a)pyrene (BaP) toxic equivalent factor $\mathrm{TEQ}_{\mathrm{Bap}}$, indicator of ecological risk, was higher in IZ. Also, the lifetime risk of cancer ILCRs model was highest in IZ.

\section{Urban soils}

Two papers in this Special Issue deal with the fourth topic, urban soils:

Khademi et al. (2020) assessed the size distribution of trace metal(oid)s in particle size fraction in urban soil and street dust in Murcia Region, SE Spain, and the influence of population density. Three urban areas with high, medium and low population density and a natural area were selected. The samples were fractioned into eight size fractions, from 2000 to $<2$ $\mu \mathrm{m}$. The concentration of $\mathrm{Pb}, \mathrm{Zn}, \mathrm{Cu}, \mathrm{Cd}, \mathrm{Cr}, \mathrm{Ni}, \mathrm{As}$ and $\mathrm{Fe}$ was determined, and enrichment factor and grain size fraction loadings were computed. The results indicated that the concentrations of $\mathrm{Pb}, \mathrm{Zn}$, $\mathrm{Cu}, \mathrm{Cd}$ and $\mathrm{Cr}$ were dependent on particle size and population density, especially for street dust. Therefore, risk assessment must be based on metals in fine particles. Fractionation of samples in two size classes using $100 \mu \mathrm{m}$ as cut-off diameter is proposed to obtain a more evaluation with the minimum cost possible.

Rehman et al. (2020) investigated the potentially toxic elements (PTE) of $\mathrm{Cu}, \mathrm{Cr}, \mathrm{Co}, \mathrm{Cd}, \mathrm{Ni}, \mathrm{Fe}, \mathrm{Zn}, \mathrm{Pb}$, $\mathrm{Mo}$ and Mn concentrations in water and soil of Chitral city, Pakistan. The authors collected and analysed water (66) and soil (48) samples for the PTE concentrations. The obtained concentrations were evaluated for the human and ecological risk assessment. The results show that the water quality was safe. For soil, the high Fe (hazard index $>1$ ) indicates non-cancer risks in children. $\mathrm{Co}, \mathrm{Ni}$ and $\mathrm{Cd}$ in soil showed higher potential ecological risk (RI) for children and only Co for adults. Elevated contamination factor $(\mathrm{CF})$ for Mo, $\mathrm{Cd}$ as well as $\mathrm{Fe}$ and moderate pollution for Mo and $\mathrm{RI}$ revealed the area as "polluted".

Agricultural soils

One paper in this Special Issue refers to the fifth topic, agricultural soils:

Peng et al. (2020) studied the content of potentially harmful elements (PHE) in agricultural soil and cereal in Jilin Province, China, and evaluated the risks to ecology and human health. In this study, 6 PHE (Zn, $\mathrm{Cu}, \mathrm{Pb}, \mathrm{Cd}, \mathrm{Hg}$ and $\mathrm{As}$ ) in 79 soil samples, 10 rice samples, 66 maize samples and 15 soybean samples from Jilin Province farmland were evaluated by three methods of pollution load index (PLI), potential ecological risk (RI) and contamination security index (CSI). The results showed that the farmland soil heavy metal pollution most serious was in the south area, followed by the east area. According to CF indexes, $\mathrm{Cu}, \mathrm{Cd}$ and $\mathrm{Hg}$ were the most polluted heavy metal in farmland soil. The biological concentration factor (BCF) showed that in the edible parts of rice, maize and soybean the order of absorption rate from soil to plants was $\mathrm{Zn}>\mathrm{Cd}>\mathrm{Cu}>\mathrm{Hg}>\mathrm{As}>\mathrm{Pb}$. The $\mathrm{HQ}, \mathrm{HI}$ and RI values showed that eating rice, maize and soybean grown in Jilin Province farmland will not cause risks to adults and children.

\section{Radionuclides}

One paper in this Special Issue refers to the sixth topic, radionuclides:

Anisimov et al. (2020) studied the combined effect of soil properties on the rate diffusion coefficients of ${ }^{60} \mathrm{Co}$ through a laboratory experiment. The authors researched the process of vertical migration of radionuclide ${ }^{60} \mathrm{Co}$ in water-saturated soil samples of disturbed structure and the same initial bulk density types, species and varieties of soils and noted a significant variance in Deff ${ }^{60} \mathrm{Co}$ for investigated soils due to different soil characteristics. An statistical approach has been used, where edaphic factors are acted as predictors and the resulting variable was Deff ${ }^{60} \mathrm{Co}$. Based on this study, the selected physicochemical properties of soils were ranked by degree of influence on the value of the dependent variable: $\mathrm{pH}_{\mathrm{kcl}}>\mathrm{Fr}_{.<0.01}>\mathrm{Fe}_{\text {mobile }}>\mathrm{P}_{2} \mathrm{O}_{5}$ mobile $>\mathrm{C}_{\text {org }}$. The experiments revealed a strong increase in the Deff ${ }^{60} \mathrm{Co}$ for soils with a high content of humus and excessive moisture.

Transfer trace elements in the ocean-atmospherecontinent system

One paper in this Special Issue deals with the seventh topic, transfer trace elements in the ocean-atmosphere-continent system: 
Korzh (2020) studied the dynamics of global flows of matter in the biosphere. The author proposed a new methodological approach to study the role of the transfer of trace elements in the ocean-atmospherecontinent system as a factor in the formation of the elemental composition of the Earth's soil cover. And he adds that the most active processes of redistribution of mean elemental compositions in the biosphere happen in the places of biogeochemical barriers such as ocean-atmosphere, river-sea and hydrospherelithosphere. These processes cause a general relative increase in the concentrations of trace elements in the environment of living organisms.

Trace elements in a permafrost-affected soil

One paper in this Special Issue refers to the eight and last topic, trace elements in a permafrost-affected soil:

Ji et al. (2020) assessed the geochemical pollution of trace metals in permafrost-affected soil in the Russian Arctic marginal environment. The authors investigated the $\mathrm{Pb}, \mathrm{Cd}, \mathrm{Cu}, \mathrm{Ni}, \mathrm{Co}, \mathrm{Zn}, \mathrm{Fe}, \mathrm{Mn}$ and $\mathrm{Hg}$ concentrations with EDX from 25 soil profiles (haplothels, turbels and historthels). Results showed different degree of organic matter decomposition and cryoturbation that caused great variability of metals distribution. Levels of $\mathrm{Fe}$ and $\mathrm{Mn}$ are considered to be geochemical background. Correlation analysis and PCA showed that trace metals are highly dependent on soil properties, and $\mathrm{Co}, \mathrm{Cu}, \mathrm{Pb}$ and $\mathrm{Hg}$ may derive from anthropogenic sources. According to some geochemical indexes, $\mathrm{Co}, \mathrm{Zn}, \mathrm{Cu}$ and $\mathrm{Pb}$ have polluted the topsoil in this area. $\mathrm{Zn}, \mathrm{Co}$ and $\mathrm{Cu}$ have higher polluted status. However, these indexes show unpolluted-to-moderate pollution and low degree of ecological risk. According to ecological indexes, Island Wrangel has the highest values.

\section{Conclusions}

The subject of this Special Issue is of great importance, and the 25 papers cover significant aspects of fundamental theoretical and applied research in soil contamination and human health and providing advances to existing knowledge.

Acknowledgements I would firstly like to thank the Co-Guest Editors, Prof. Dr. Elena Korobova (Vernadsky Institute of
Geochemistry and Analytical Chemistry, Moscow, Russian Federation), Prof. Dr. V.V.Ermakov (Vernadsky Institute of Geochemistry and Analytical Chemistry, Moscow, Russian Federation), Prof. Dr. Carmen Pérez-Sirvent (Faculty of Chemistry, University of Murcia, Spain), Prof. Dr. Michael J. Watts (School of Biosciences, University of Nottingham) for their valuable collaboration. Moreover, I would like to thank the authors for their contributions and for their patience with the review process as well as the reviewers for their observations. Their efforts have improved the quality of this Special Issue. Help with English from James Dove and IT assistance from Oriol Bech is also greatly appreciated. I am extremely grateful to Prof. Dr. Ming Hung Wong Editor-in-Chief of EGAH, Dr. Sherestha Saini Senior Editor, Ms. Sherine Joseph Handling Editor and Mindy Wang, Assistant to Prof. MH Wong. Without knowledge and experience this Special Issue could never have been published.

\section{References}

Anisimov, V. S., Dikarev, D. V., Kotchetkov, I. V., Ivanov, V. V., Anisimova, L. N., Tomson, A. V., Korneev, Y. N., \& Frigidov, R. A. (2020). The study of the combined effect of soil properties on the rate of diffusion of ${ }^{60} \mathrm{Co}$ (this special issue).

Egorova, D. O., \& Buzmakov, S. A. (2020). Carcinogenic and teratogenic status of human population and polychlorinated biphenyls contaminations of soils and biota (European pied flycatcher) in a Perm (Western Ural, Russia) (this special issue).

Han, H.-J., Lee, J.-U., Ko, M.-S., \& Kim, K.-W. (2020). Comparison of five extraction methods for evaluating cadmium and zinc immobilization in soil (this special issue).

Ji, X., Abakumov, E., Tomashunas, V., Polyako, V., \& Kouzov, S. (2020). Geochemical pollution of trace metals in permafrost-affected soil in the Russian Arctic marginal environment (this special issue).

Jiang, S., Liu, J., Dai, G., Wu, J., Wei, D., \& Shu, Y. H. (2020). Assessing biochar application to immobilize $\mathrm{Cd}$ and $\mathrm{Pb}$ in a contaminated soil: a field experiment under a cucumbersweet potato-rape rotation (this special issue).

Kapwata, T., Mathee, A., Sweijd, N., Minakava, N., Mogotsi, M., Kunene, Z., \& Wright, C. (2020). Spatial assessment of heavy metals contamination in household garden soils in rural Limpopo Province, South Africa (this special issue).

Khademi, H., Gabarrón, M., Abbaspour, A., Martínez-Martínez, S., Faz, A., \& Acosta, J. A. (2020). Distribution of metal(loid)s in particle size fraction in urban soil and Street dust: influence of population density (this special issue).

Khelifi, F., Melki, A., Hamed, Y., Adamo, P., \& Caporale, A. G. (2020). Environmental and human health risk assessment of potentially toxic elements in soil, sediments and oreprocessing wastes from a mining area of southwestern Tunisia (this special issue).

Ko, M.-S., Nguyen, T. H., Kim, Y.-G., Linh, B. M., Chanpiwat, P., Hoang, H. N. T., Huing, N. T. A., Tuyen, L. H., Quoc, B. N., Anh, N. V., \& Kim, K.-W. (2020). Assessment and source identification of $\mathrm{As}$ and $\mathrm{Cd}$ contamination in soil 
and plants in the vicinity of the Nui Phao Mine, Vietnam (this special issue).

Korzh, V. D. (2020). Transfer of trace elements in the oceanatmosphere-continent system as a factor in the formation of the elemental composition of the Earth's soil cover (this special issue).

Kumar, R., Mittal, S., Peechat, S., Sahoo, P. R., \& Sahoo, S. K. (2020b). Quantification of groundwater-agricultural soil quality and associated health risks in the agri-intensive Sutlej River Basin of Punjab, India (this special issue).

Kumar, A., Tripti, T., Maleva, M., Kiseleva, I., Maiti, S. K., \& Morozova, M. (2020a). Toxic metal(oid)s contamination and potential human health risk assessment in vicinity of century old copper smelter, Karabash, Russia (this special issue).

Linnik, V., Minkina, T., Bauer, T., Savaliev, A., \& Mandzhieva, S. (2020). Geochemical assessment and spatial analysis of heavy metals pollution around a coalfired power station (this special issue).

Mishra, T., Pandey, V. Ch., Praveen, V. M., Singh, N. B., Singh, N., \& Singh, D. P. (2020). Phytoremediation ability of naturally growing plant species on the electroplating wastewater contaminated site (this special issue).

Naz, A., Chowdhury, A., Chandra, R., \& Mishra, B. K. (2020). Potential human health hazard due to bioavailable heavy metal exposure via consumption of plants with ethnobotanical usage at the largest chromite mine of India (this special issue).

Nguyen, T. H., Hoang, H. N. T., Nguyen,Q. B., \& Kim, K.-W. (2020). Contamination of heavy metals in paddy soil in the vicinity of Nui Phao multi-metal mine, North Vietnam (this special issue).

Parvanak, K., \& Khamisabadi, A. (2020). Evaluation of irrigated soils with wastewater using pollution indicators (a case study of Zahedan) (this special issue).

Peng, J., Li, F., Zhang, J., Chen, Y., Cao, T., Tong, Z., Liu, X., Liang, X., \& Zhao, X. (2020). Comprehensive assessment of heavy metals pollution of farmland soil and crops in Jilin Province (this special issue).

Pobi, K. K., Nayek, S., Gope, M., Rai, A. K., \& Saha, R. (2020). Sources evaluation, ecological and health risk assessment of potential toxic metals (PTMs) in surface soils of an industrial area, India (this special issue).

Rehman, I.u., Ishaq, M., Ali, L., Muhammad, S., Din, I. U., Yaseen, M., \& Ullah, H. (2020). Potentially toxic elements occurrence and risk assessment through water and soil of Chitral urban environment, Pakistan: A case study (this special issue).

Rossini-Oliva, S., Abreu, M. M., Santos, E. S., \& Leidi. E. O. (2020). Soil-plant system and potential human health risk of Chinese cabbage and oregano growing in soils from Mnand Fe-abandoned mines: Microcosm assay (this special issue).

Sanwar, T., Shahid, M., Natasha, N., Khalid, S., Shah, A. H., Ahmad, N., Naeem, M. A., Haq, Z. U., Murtaza, B., \& Bakhat, H. F. (2020). Quantification and risk assessment of heavy metals buildup in soil-plant system after irrigation with untreated city wastewater in Vehari, Pakistan (this special issue).

Tao, H., Wang, Y., Liang, H., Li, J., Liu, X., \& Zhang, X. (2020). Pollution characteristics of phthalate acid esters in agricultural soil of Yinchuan, northwest China and health risk assessment (this special issue).

Zhang, J., Yang, J., Yu, F., Liu, X., \& Yu, Y. (2020). Polycyclic aromatic hydrocarbons in urban greenland soils of Nanjing, China: Concentration, distribution, sources, and potential risks (this special issue).

Publisher's Note Springer Nature remains neutral with regard to jurisdictional claims in published maps and institutional affiliations. 